\title{
Rod Consolidation at the West Valley Demonstration Project
}

December 1986

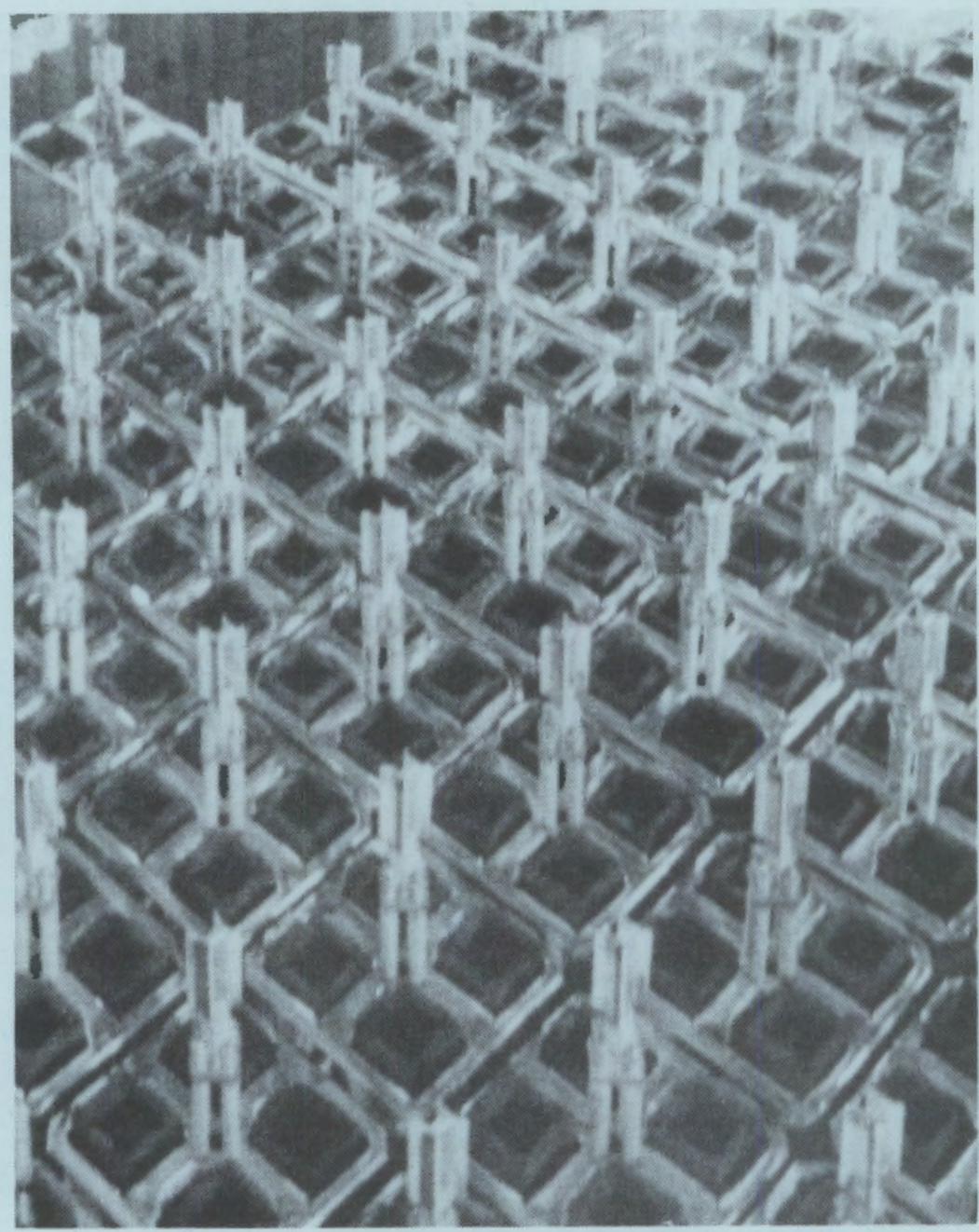

Prepared for the U.S. Department of Energy under Contract DE-AC06-76RLO 1830

Pacific Northwest Laboratory Operated for the U.S. Department of Energy By Battelle Memorial Institute 


\title{
DISCLAIMER
}

This report was prepared as an account of work sponsored by an agency of the United States Government. Neither the United States Government nor any agency thereof, nor Battelle Memorial Institute, nor any of their employees, makes any warranty, expressed or implied, or assumes any legal liability or responsibility for the accuracy, completeness, or usefulness of any information, apparatus, product, or process disclosed, or represents that its use would not infringe privately owned rights. Reference herein to any specific commercial product, process, or service by trade name, trademark, manufacturer, or otherwise, does not necessarily constitute or imply its endorsement, recommendation, or favoring by the United States Government of any agency thereof, or Battelle Memorial Institute. The views and opinions of authors expressed herein do not necessarly state or reflect those of the United States Government or any agency thereof, or Battelle Memorial Institute.

\author{
PACIFIC NORTHWEST LABORATORY \\ operated by \\ BATTELLE \\ for the \\ UNITED STATES DEPARTMENT OF ENERGY \\ under Contract DE-ACO6-76RLO 1830
}

\begin{tabular}{|c|c|}
\hline Printed in the & 5 of America \\
\hline & \\
\hline National Techr & tion Service \\
\hline United States & f Cornmerce \\
\hline 5285 & ad \\
\hline Springfi & 22161 \\
\hline NTI & \\
\hline & \\
\hline & \\
\hline & Price \\
\hline Pages & Codes \\
\hline 001-025 & $\mathrm{A} 02$ \\
\hline 026-050 & $\mathrm{A} 03$ \\
\hline 051-075 & A04 \\
\hline $076-100$ & A05 \\
\hline $101-125$ & A06 \\
\hline $126-150$ & $\mathrm{~A} 07$ \\
\hline $151-175$ & A06 \\
\hline $176-200$ & $\mathrm{~A} 09$ \\
\hline $201-225$ & A010 \\
\hline $226-250$ & A011 \\
\hline $251-275$ & A012 \\
\hline $276-300$ & A013 \\
\hline
\end{tabular}


ROD CONSOLIDATION AT THE

WEST VALLEY DEMONSTRATION PROJECT

W. J. Bajley

December 1986

Prepared for the U.S. Department of Energy under Contract DE-ACO6-76RLO 1830

Pacific Northwest Laboratory

Richland, Washington 99352 



\section{SUMMARY}

A rod consolidation demonstration with irradiated pressurized water reactor (PWR) fuel was recently conducted by personnel from Nuclear Assurance Corporation and West Valley Nuclear Services Company at the West Valley Demonstration Project in West Valley, New York. The rod consolidation demonstration involved pulling all of the fuel rods from six fuel assemblies. In general, the rod pulling proceeded smoothly. The highest compaction ratio attained was 1.8:1. Among the total of 1074 fuel rods were some known degraded rods (they had collapsed cladding, a result of in-reactor fuel densification), but no rods were broken or dropped during the demonstration.

Personnel from Pacific Northwest Laboratory (PNL) visited the site several times to observe and discuss the rod consolidation activities. One of PNL's interests was in gathering information on the effect of rod consolidation operations on the integrity of the fuel rods during subsequent handling and storage. Another of PNL's interests was in collecting information on the condition and handling of intact, damaged, and failed fuel that has been in storage for an extended period. PNL's observations, conclusions, and recommendations are provided in this report. 


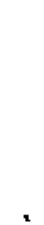




\section{ACKNOWLEDGMENTS}

This report summarizes a study conducted by Pacific Northwest Laboratory (PNL) for the Commercial Spent Fuel Management Program sponsored by the U.S. Department of Energy (DOE) under Contract No. DE-AC06-76RL0 1830. Principal Investigator was W. J. Bailey of the Nuclear Fuels and Materials Department. The author acknowledges the contributions of R. J. Guenther (Nuclear Fuels and Materials Department) and L. A. Stope (Applied Physics Center) of PNL, A. A. Fuierer of Rochester Gas and Electric Corporation, C. B. Woodhall of Nuclear Assurance Corporation, R. E. Stiens of DOE's West Valley Project Office, and P. S. Klanian of West Valley Nuclear Services Company. 


\section{CONTENTS}

SUMMARY. . . . . . . . . . .............

ACKNOWLEDGMENTS. . . . . . . . . . . . . . . . . v v

1.0 INTRODUCTION . . . . . . . . . . . . . . . . . . . . . . . . . . . . .

2.D CONCLUSIONS AND RECOMMENDATIONS. . . . . . . . . . . . . 3

3.0 ROD CONSOLIDATION OPERATIONS ON PWR FUEL ASSEMBLIES

AT THE WEST VALLEY SITE. . . . . . . . . . . . . . . . . . 7

REFERENCES .......................... . . 21 
•

ฯ 
1 Spent Fuel Assemblies in the Spent Fuel Storage Pool at the West Valley Site. ................ . 7

2 Fuel Assembly Being Pulled Out of Aluminum Storage Canister. . . . . 8

3 Elevator and Underwater Rod Consolidation Equipment with a Fuel Assembly in the Process of Having a Fuel Rod Pulled . . . . . . 9

4 Operators on the Working Platform in the Process of Pulling a Fuel Rod from a Fuel Assembly. . . . . . . . . . . . 10

5 Elevator Winch and Floating Window ............. 11

6 Fuel Rod After Typical Snatch-and-Jerk Motion Initiated to Loosen Rod from Fuel Assembly and Before Collet Retightened to Continue Pulling Rod from Assembly. . . . . . . . . . 12

7 Fuel Rod that Exhibits Region with Collapsed Cladding as the Rod is Being Pulled from a Fuel Assembly . . . . . . . . . . . 14

8 Fuel Rod with Collapsed Cladding that Released a Bubble of Fission Gas as the Rod was Being Pulled from the Fuel Assembly. . . . 15

$\underline{\text { TABLE }}$

1 Compaction Ratios Attained at the West Valley Site. . . . . . . 16 


\section{T.0 INTRODUCTION}

Rod consolidation involves mechanically removing the fuel rods from the fuel assembly hardware (i.e., the nonfuel-bearing structural components) and placing them either in another grid with closer spacing or in a close-packed array in a canister without a spacer grid. Rod consolidation is a leading candidate for yielding more efficient utilization of existing space in spent fuel storage pools.

Rod consolidation operations with six irradiated PWR fuel assembities were recently demonstrated at the West Valley Demonstration Project (Fuierer 1986). That project is at the Western New York Nuclear Service Center, which is located at West Valley, New York, and is operated by West Valley Nuclear Services Co., Inc. (i.e., Westinghouse Electric Corporation) for the U.S. Department of Energy (DOE). The facility, which was formerly a nuclear fuel reprocessing center, was built and previously operated by Nuclear Fuel Services (NFS). The fuel assemblies had been stored in the facility's spent fuel storage pool since 1973. Spent fuel storage at, and characteristics of, the facility are described in a 1982 paper (Duckworth 1982).

The demonstration was a cooperative program sponsored by the Empire State Electric Energy Research Corporation (ESEERCD); Rochester Gas and Electric Corporation (RG\&E); Nuclear Assurance Corporation (NAC); New York State Energy Research and Development Authority, which is an agency of the State of New York; the DOE; and Electric Power Research Institute (EPRI). The actual rod consolidation operations were conducted through an arrangement between NAC and ESEERCO and involved personnel from NAC and West valley Nuclear Services Company. A follow-on program to the West Valley rod consolidation demonstration was proposed by $\mathrm{RG}^{(\mathrm{a}}{ }^{(a)}$ and recently authorized by DOE. That work commenced in July 1986. The follow-on program involves rod

(a) Fuierer, A. A., Rochester Gas and Electric Corporation. 1986. Letter to Owight Shelor, U.S. Department of Energy, "Proposal for Work as a Follow-On to the West Valley Program," March 25, 1986. 
consolidation operations at Battelle Columbus Laboratories ( $B C L$ ) on seven irradiated PWR fuel assemblies that had been shipped to BCL prior to July. One of the assemblies shipped to BCL contains several rods that are visibly deformed; each rod has a short section, $2.5-$ to $7.5-\mathrm{cm}$ ( 1 - to 3-in.) long, where the cladding has collapsed due to fuel pellet densification during reactor service. However, no rupture of the cladding is evident.

Personnel from Pacific Northwest Laboratory (PNL) ${ }^{(a)}$ who are engaged in studies sponsored by the DOE on the Commercial Spent Fuel Management (CSFM) Program visited the West Valley site on several occasions to observe and discuss the rod consolidation activities. One of PNL's interests was in gathering information on the effect of rod consolidation operations on the integrity of the fuel rods during subsequent handling and storage. Another of PNL's interests was to collect information on the condition and handing of intact, damaged, and failed fuel that has been in storage for an extended period.

(a) Operated by Battelle Memorial Institute for the Department of Energy under Contract DE-ACO6-76RLO 1830. 


\subsection{CONCLUSIONS AND RECOMMENDATIONS}

The rod consolidation demonstration at the West Valley site provides further evidence that rod breakage is a relatively infrequent occurrence even when fuel assemblies containing defective fuel rods are intentionally selected for examination, reconstitution, or rod consolidation. To date, domestic experience shows that only about six rods out of a biased sample of fuel assemblies containing over 52,000 fuel rods broke during examination, reconstitution, and rod consolidation activities (Klein, Johnson, and Bailey 1986; Bailey and Beeman 1985; Bailey 1985). The likelihood for rod breakage is potentially higher for fuel rods with large cladding defects.

During the demonstration at the West Valley site, interference with a spacer grid resulted in the release of a bubble of fission gas from a rod with collapsed cladding. Operators estimated the bubble to be baseballto-grapefruit size. No significant consequence resulted from the release of the fission gas, and operators were able to resume work shortly after vacating the working platform and taking necessary precautions.

Based on the videotapes, it appears that no substantial damage to cladding occurred that was attributable to the consolidation operation, although longitudinal scratch marks are visible on most rods. As expected, the marks are similar to those encountered as a result of rod removal for examination or fuel assembly reconstitution. The marks appear to be superficial and the result of the crud layer being scraped off as the rod passed through the spacer grids. No fuel rods broke and, according to NAC, no other known fuel rod damage occurred during the rod consolidation program.

In comparison to the rod pulling forces noted in the earlier Duke Power Company/Westinghouse Electric Corporation rod consolidation demonstration program (ANS 1983; Bassler 1984; Duke-Westinghouse 1983) and to the data available from reconstitution operations at other sites, the continuous pulling forces required at West valley (averaged about 41 kilograms or 90 pounds) were considerably greater. In general, rod pulling proceeded smoothly. A pulling force of approximately 91 kilograms (200 pounds) was 
reached on the stuck rod that released the fission gas bubble and on another rod that was stuck; however, the eventual removal of both rods required much lower pull forces. NAC noted that in neither case did these high pull forces appear to damage the rods.

Crud that came loose or was scraped loose from the rods did not result in an increase in pool water radioactivity and water clarity was maintained (Fuierer 1986). However, the water inside the rod consolidation canister clouded up because of crud released from fuel rods as they were inserted into the canister.

According to RGEE, the surprising flexibility and resiliency of the fuel rods create a problem in achieving compaction ratios close to $2: 1$ with rod consolidation techniques that do not employ a transition device (such as the technique used at West valley). This flexibility and resiliency were demonstrated frequently during the rod consolidation operations at West valley. A transition device helps hold the rods in a closely packed array as the rods enter the canister. The resiliency exhibited by the rod 1) has the benefit of providing confidence that fuel rods can withstand considerable abuse in handling without rupture or breakage, 2) has the disadvantage that directional and alignment control during stacking operations is extremely difficult, and 3 ) indicates that rods must be constrained during rod consolidation operations if high compaction ratios are to be achieved. Because of the inherent flexibility, a bowed rod in a fuel assembly will likely straighten out somewhat when it is removed from the assembly and suspended vertically from its end. Therefore, RG\&E concludes that the evidence from the rod consolidation operations at West valley indicates that bowed rods will not be a problem once removal of those rods from a fuel assembly begins.

Pulling rods one at a time appears to be a slow operation; however, NAC points out that rod pulling, per se, is only a small part of a rod consolidation program. Other issues (procedures, quality assurance, etc.) associated with the program that are considered secondary are the real time consumers. With single-rod pulling, a horizontal operation may be better than a vertical operation (the type used at West valley) if compaction ratios close to $2: 1$ are desired, because the former would be aided by the force of gravity. 
When rods are pulied out of the fuel assembly one at a time and then placed in a canister one at a time, a difficult procedure is required to maneuver the rods into a close-packed array when no transition device is employed. At West Valley no transition device was used, and the highest compaction ratio achieved was 1.8:1. However, after reviewing the operation on that canister, NAC concluded that with additional control, another 16 or 17 fuel rods could have been loaded into that canister. In any event, NAC now believes that even the relatively simple rod consolidation system used at West Valley can routinely achieve consolidation ratios of 1.8 to 1.9. NAC aiso considers these results to be clear evidence of the need for mechanical rod constraint and direction to lessen the demand upon human skills.

The rod consolidation activities at west valley did not result in significant personnel exposure. An exposure level of $0.6 \mathrm{mrem} / \mathrm{h}$ in a 1 to $2 \mathrm{mrem} / \mathrm{h}$ background level was experienced (Fuierer 1986).

Recommendations are as follows:

- Quantitative data on the scratches produced specifically by rod consolidation activities as a function of rod pulling force would be desirable for evaluation of the various rod consolidation techniques (e.g., vertical and horizontal rod orientation, single-rod and multiple-rod pulling, wet and dry environment). Such data from mounted specimens could include measurements of scratch depths and photomicrographs that show whether the scratches penetrate the crud layer, the crud plus oxide layers, or the underlying metal surface. It would also be desirable to obtain data on rod pulling force as a function of initial spring-to-rod forces in spacer grids, contact area, and burnup. These data would aid in predicting trends on pulfing forces and scratches.

- The ability to physically position the rod during its insertion into the canister is extremely important and is an area that needs considerable engineering attention. 
- Good television cameras and good lighting are essential for rod consolidation activities and for monitoring fuel rod integrity. However, NAC points out that there is a tradeoff between information gathered and interference with underwater operations.

- Having a camera-equipped periscope available during rod consolidation operations would facilitate closer monitoring and better documentation of fuel rod integrity during those operations by permitting more detailed study of rod damage (scratches, dents, etc.), changes in rod surface appearance (e.g., scraping off of crud), and changes in rod defects (defects produced by handling/shipping prior to rod consolidation, irradiation-induced defects, etc.). 


\subsection{ROD CONSOLIDATION OPERATIONS ON PWR FUEL ASSEMBLIES AT THE WEST VALLEY SITE}

The rod consolidation demonstration at the West Valley site was performed in late December 1985 and in February 1986 in the 14-m (45-ft) deep cask unloading pool (CUP), which adjoins the spent fuel storage pool. The pool is $23 \mathrm{~m}$ (75 ft) long, $12 \mathrm{~m}$ (40 ft) wide, and $8.8 \mathrm{~m}(29 \mathrm{ft})$ deep, and is normally filled with demineralized water to a depth of $8.5 \mathrm{~m}$ (28 ft) (Duckworth 1982). The spent fuel pool has concrete walls (painted with "Carboline"). The walls of the CUP are clad with stainless steel. Figure 1 shows spent fuel assemblies in the storage racks in the pool. The fuel storage racks consist of an aluminum beam structure that provides a total capacity of 924 fuel storage canisters. The aluminum storage canisters (see Figure 1) have an inside

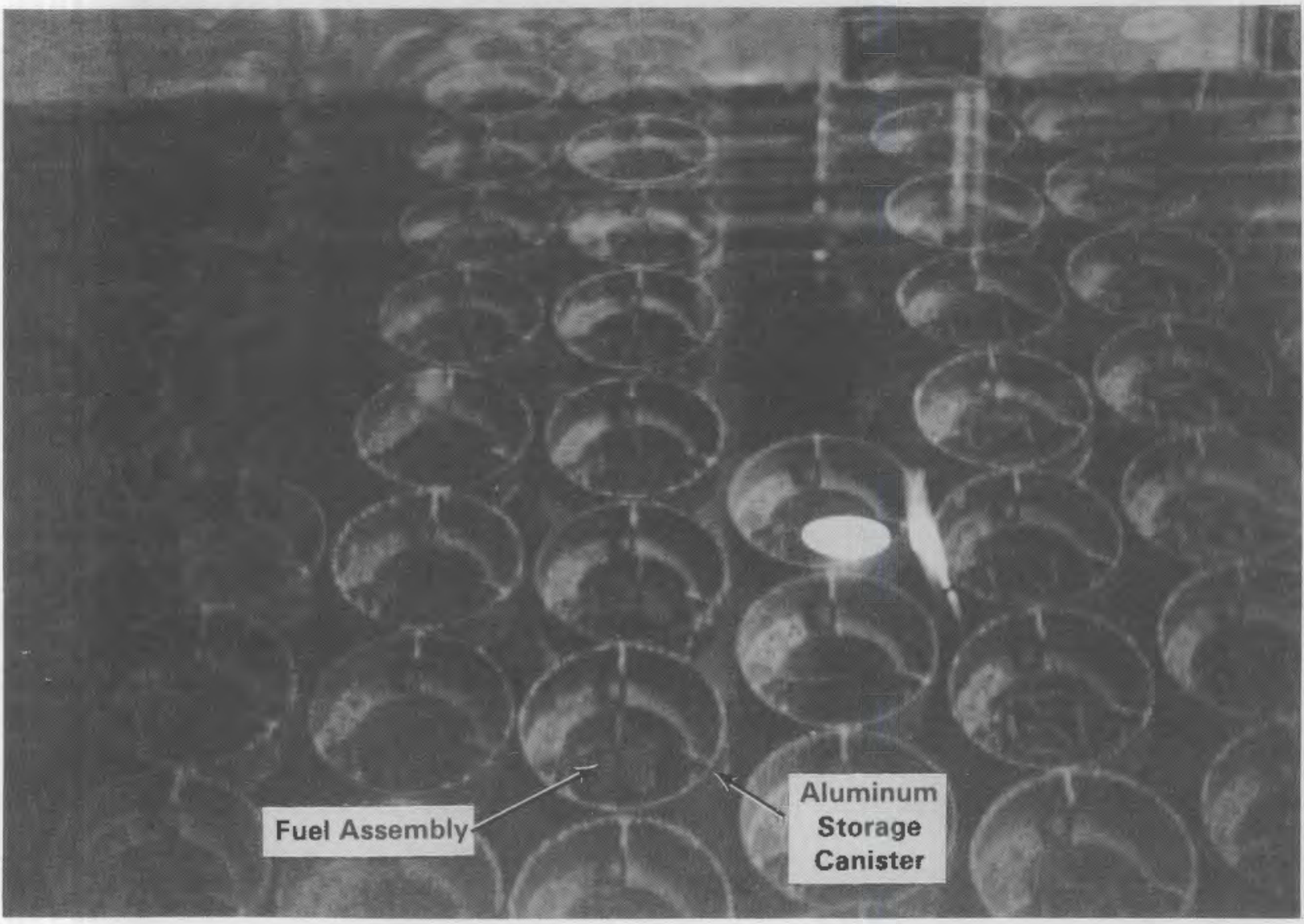

FIGURE 1. Spent Fuel Assemblies in the Spent Fuel Storage Pool at the West Valley Site 
diameter of $31.8 \mathrm{~cm}(12.5 \mathrm{in.})$ and a center-to-center spacing of $51.4 \mathrm{~cm}$ (20.25 in.) (Ouckworth 1982). A storage canister is up to $4.9 \mathrm{~m}(16 \mathrm{ft}$ ) long and can accommodate one pressurized water reactor (PWR) fuel assembly or two or three boiling water reactor (BWR) fuel bundles. (a) These aluminum storage canisters have been in the pool for over 20 years. The West Valley site has indicated (Duckworth 1982) that they have found the aluminum to be very sensitive to water quality and $\mathrm{pH}$ control. If the water becomes too acidic ( $\mathrm{pH}$ less than 6.0 ), oxide barnacles form (Figure 2) and become contaminated and make the aluminum difficult to decontaminate and handle.

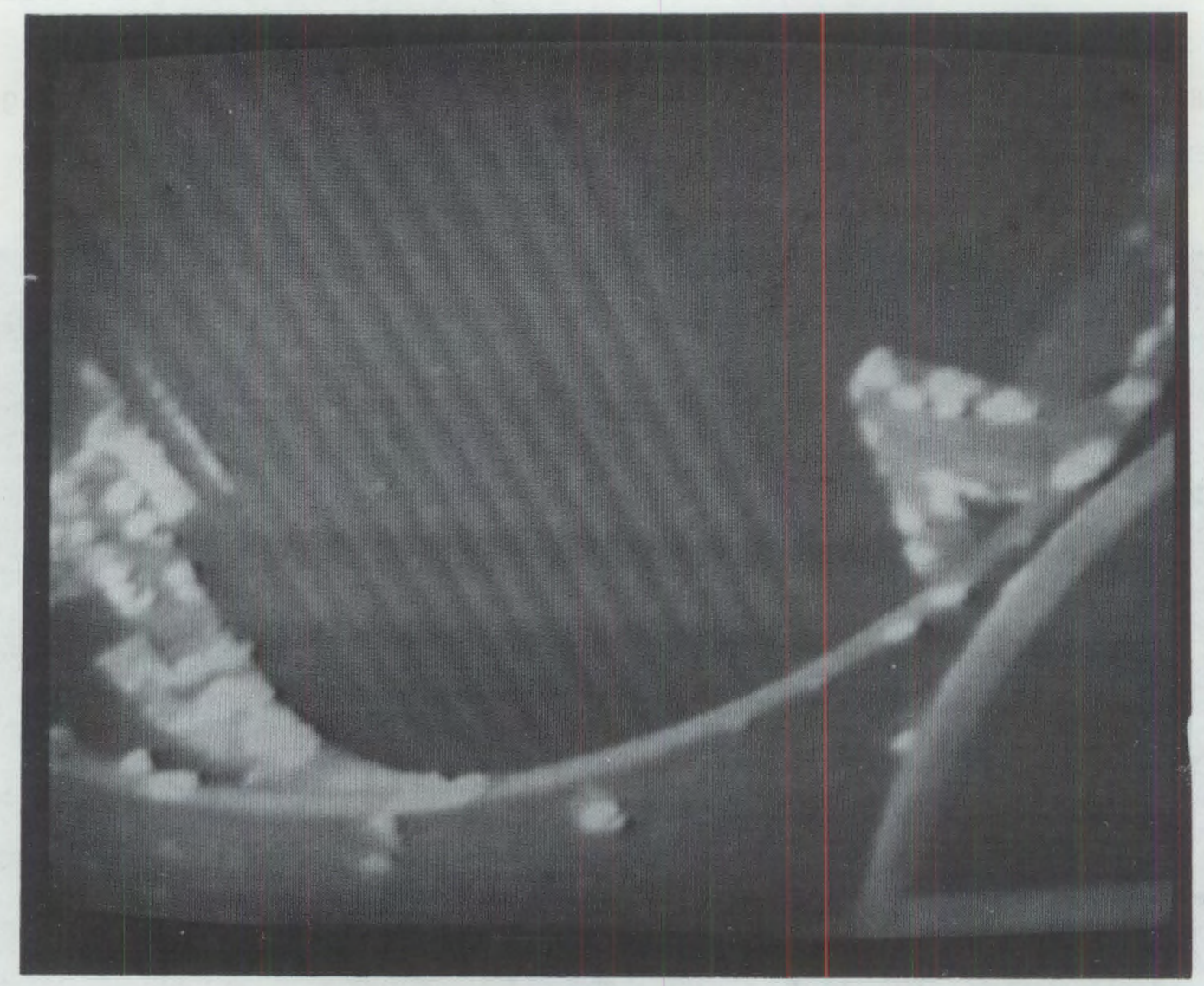

FIGURE 2. Fuel Assembly Being Pulled out of Aluminum Storage Canister. (The white patches are oxide barnacles that formed on the aluminum during the 20 years in the pool.)

(a)The terms "fuel assembly" and "fuel bundle" are used interchangeably by the nuclear industry, al though generally the former term is associated with fuel for PWRs and the latter term with fuel for BWRs. A BWR fuel assembly consists of a fuel bundle and the open-ended channel that encloses the bundle. 
The Nuclear Assurance Corporation's rod consolidation equipment is shown in Figures 3 through 5 . All of the rod consolidation equipment went into the pool fairly easily. The elevator (Figure 3), which holds the fuel assembly being consolidated and the associated underwater equipment, is moved by the winch on the vertical track on the pool wall (Figures 4 and 5). The fuel rods are grappled with a hydraulically-operated collet (Figure 6), and vertical movement is initiated with a snatch-and-jerk motion (Fuierer 1986; Johnson 1986). The rod is typically pulled out a short distance and the collet is loosened, as shown in Figure 6 , and then retightened. A small amount of crud is released (visible on the videotapes) from the gripped end of the rod as a result of this action on the collet. A rod is subsequently pulled from the fuel assembly by maintaining the grip on the rod's upper end and lowering the fuel assembly with the elevator.

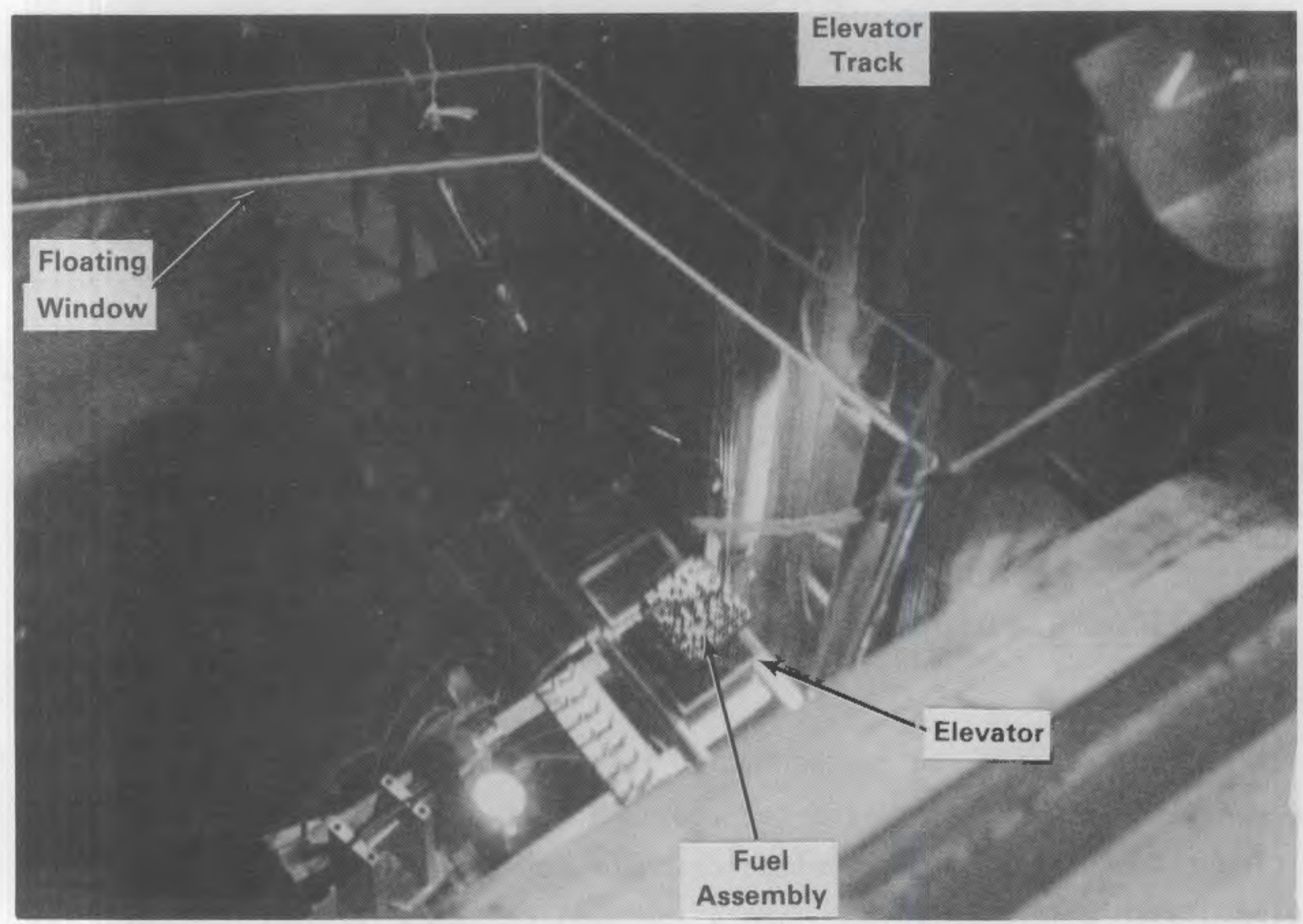

FIGURE 3. Elevator and Underwater Rod Consolidation Equipment with a Fuel Assembly in the Process of Having a Fuel Rod Pulled 


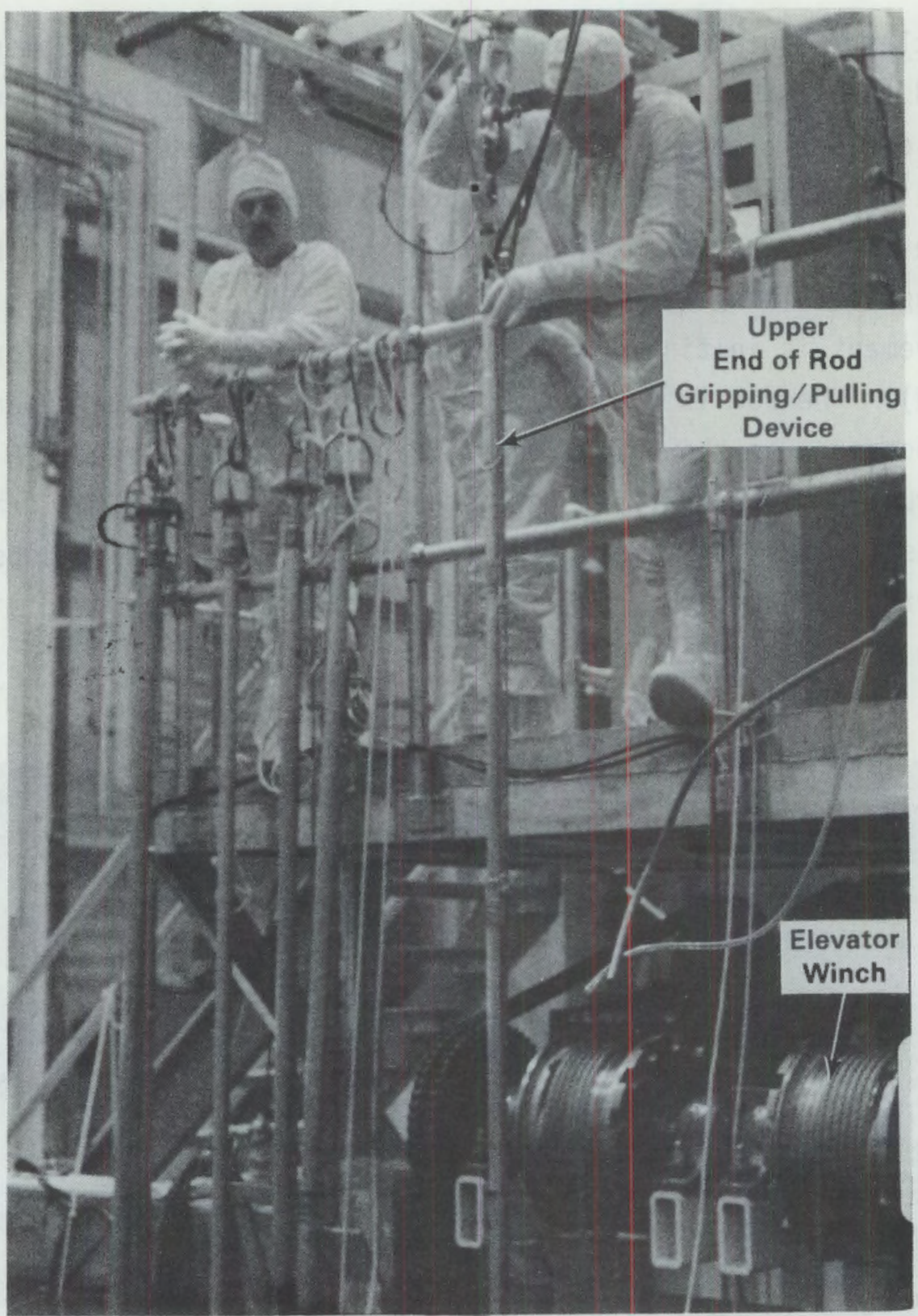

FIGURE 4. Operators on the Working Platform in the Process of Pulling a Fuel Rod from a Fuel Assembly

The free-hanging rod is then moved to a position above the open top of the consolidation canister, and the rod is inserted into the canister by raising the canister with the elevator. The rod gripping/pulling device is equipped with a load cell that limits the pulling force to about 113 to 136 kilograms (250 to 300 pounds). Force of about 91 kilograms (200 pounds) is required to pull the rod from the gripping device. 


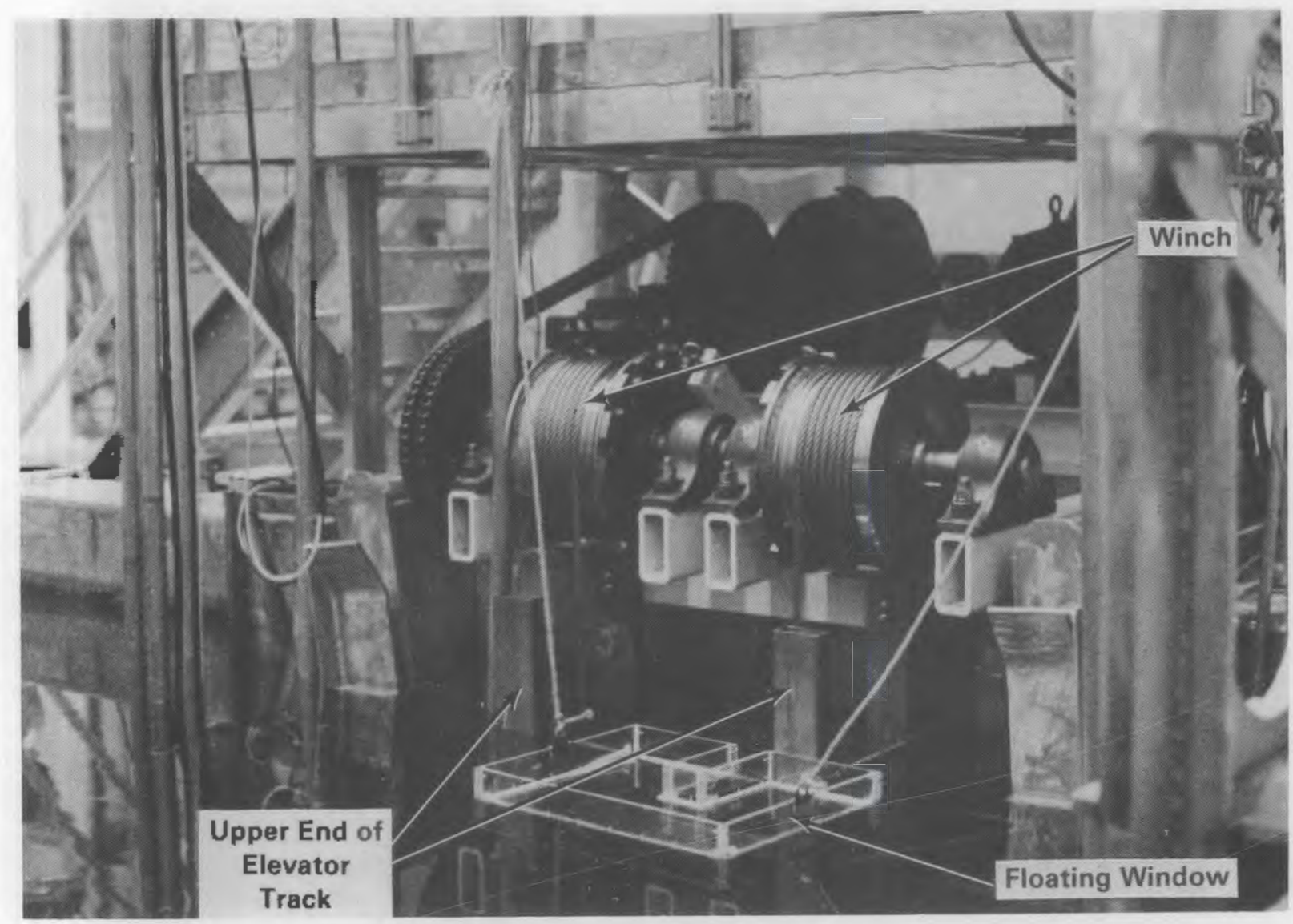

FIGURE 5. Elevator Winch and Floating Window

When PNL was at the West Valley site on February 24, 1986, some difficulty was observed in positioning the gripping device on a rod end (the device slipped by or off the rod ends a number of times). NAC indicated that this difficulty in positioning the gripping device is due to problems caused by fuel rods with squared-off (flat) ends (Figure 6 ) and to differing human skill levels. Some rods with chamfered ends tended to guide the collet onto the rod ends. Some operators were able to grip even the flat-ended rods easily; other operators had difficulty. The floating windows (Figures 3 and 5) were available at the facility and aided the operators in viewing the fuel assembly and other underwater items by eliminating water surface perturbations.

There is a crushing and shearing device on the side of the pool wall next to the elevator. The upper and lower end fittings from the fuel assemblies were placed intact into a storage box; no attempt was made (or 


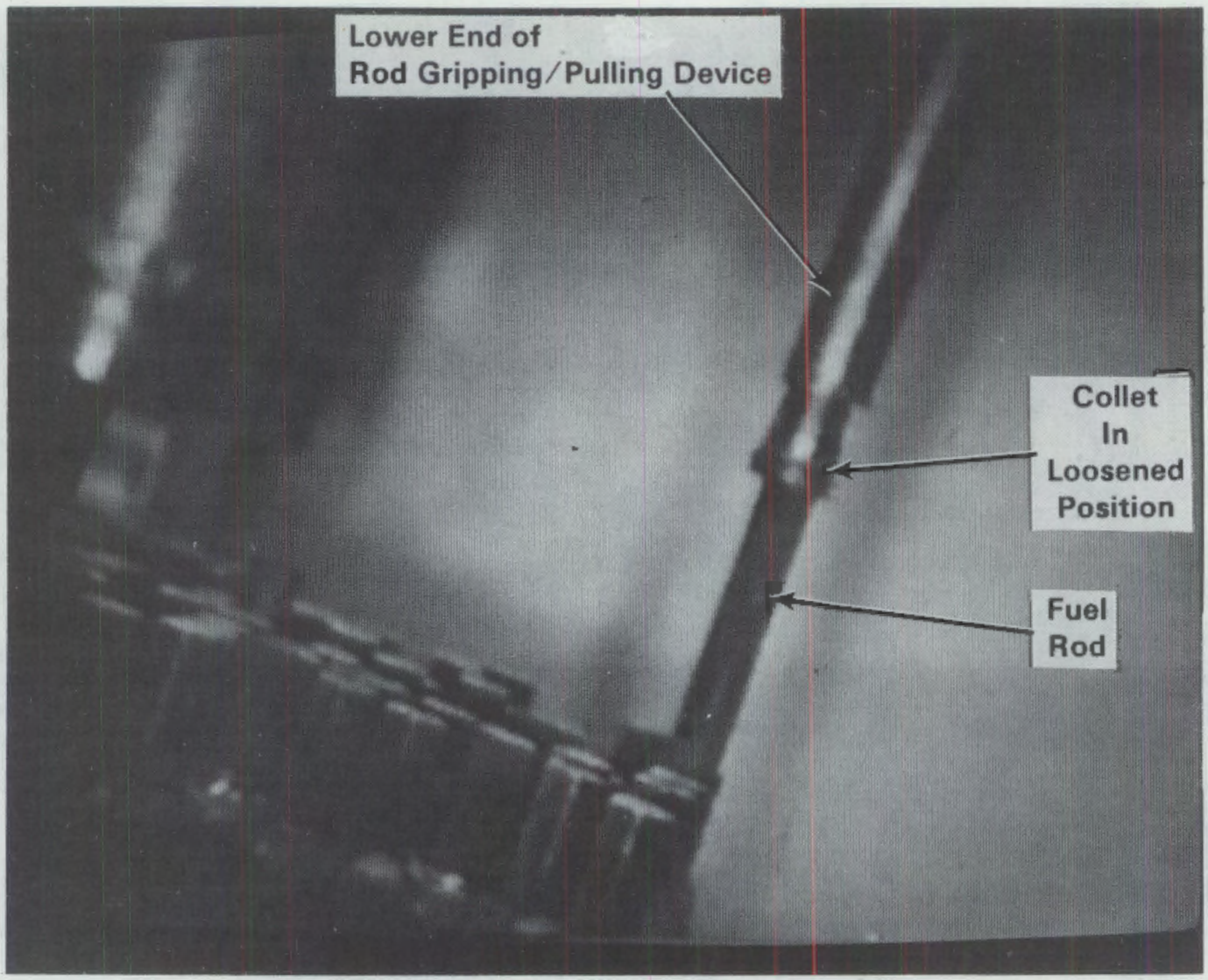

FIGURE 6. Fuel Rod After Typical Snatch-and-Jerk Motion Initiated to Loosen Rod from Fuel Assembly and Before Collet Retightened to Continue Pulling Rod from Assembly

intended) to crush or shear them. The spacer grids were crushed, and the tubes (sixteen control rod guide tubes and one instrumentation tube per fuel assembly) were crushed and sheared into short lengths before being placed in the storage box.

There are three spaces for fuel assemblies on the elevator: 1) a space for the fuel assembly being consolidated, 2) a space for the square consolidation canister in which the rods are placed, and 3) a space for a failed fuel canister. The canisters have screened flow passages in the top and bottom that can be either open or closed for coolant circulation during canister storage. The failed fuel canister was designed to hold up to 75 failed or broken rods, which would be placed into $1.9-\mathrm{cm}(3 / 4-$ inch) diameter stainless 
steel tubes within the canister. However, no failed fuel rods were placed into the failed fuel canister during the consolidation operations. (a)

The rod consolidation demonstration involved six irradiated PWR fuel assemblies from RG\&E's Ginna plant. Each fuel assembly contained 179 fuel rods. The fuel assembly burnups were in the 20,000 to 22,000 MWd/MTU range. The fuel assemblies had been stored in the pool at the West Valley site since 1973 (Duckworth 1982). RG\&E indicated that the fuel assemblies selected for consolidation did not include hydrided fuel (Fuierer 1986). Hydrided fuel could exhibit structural weakness and make handling and consolidation activities more difficult. All of the fuel rods (a total of 1074) were pulled from the assemblies and placed in consolidation canisters. Among the fuel rods were some with collapsed cladding (Figure 7), which is a result of in-reactor fuel densification.

During the rod consolidation demonstration, videotapes were made of all fuel rods for records and accountability purposes. Good television cameras and good lighting are essential for rod consolidation activities (and for monitoring fuel rod integrity aspects). (b) The pool at the West valley site was not equipped with a periscope. R. E. Stiens of DOE's West Valley Project Office provided PNL with copies of several of the videotapes that contained examples of items that were pertinent to this report. In attempting to prepare some of the illustrations for this report, PNL encountered difficulty in producing photographs of satisfactory quality from the videotapes. Pertinent details readily apparent on the videotapes are not always evident in the photographs, even though the best equipment available at PNL was used (i.e., a Harris unit with freeze-frame capability).

(a) All of the rods handled during rod consolidation were considered failed fuel for shipping purposes. A failed rod to be placed into the rod consolidation "failed fuel canister," if encountered, would have been a sheared or broken rod. The NRC definition of "pinhole leaks or hair-line cracks" was not adhered to since all consolidated fuel was shipped as failed fuel.

(b) Stiens, R. E. (West Valley Project Office, DOE). 1985. Memorandum to C. P. Gertz (Radioactive Waste Technology Division, DOE), "Rod Consolidation Project," dated December 30, 1985. 


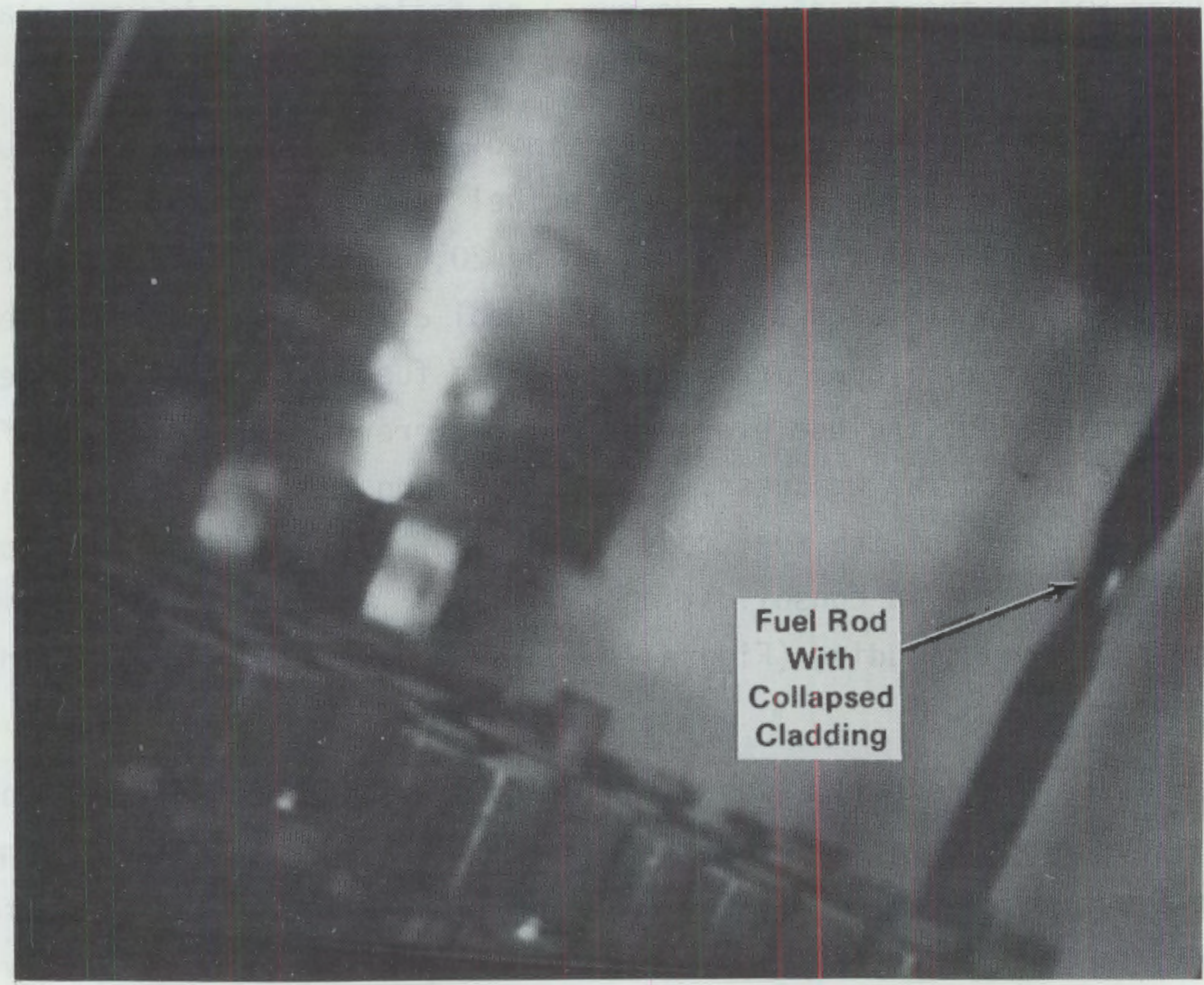

FIGURE 7. Fuel Rod that Exhibits Region with Collapsed Cladding as the Rod is Being Pulled from a Fuel Assembly

No rods were broken or dropped during the demonstration at the West Valley site. After they had been partially pulled from the assemblies, several rods stuck because of flat spots (areas where the cladding had collapsed). However, those rods were freed by slightly twisting them to align the long (transverse) dimension of the flattened cross section along the diagonal of the spacer grid (Fuierer 1986). During the rod demonstration, interference with a spacer grid resulted in the release of a bubble of fission gas from a rod with collapsed cladding (Figure 8). Operators estimated the bubble to be baseball-to-grapefruit size (Fuierer 1986). RG\&E reported that no significant consequence resulted from the release of fission gas and that operators resumed work after vacating the working platform and taking necessary precautions. 


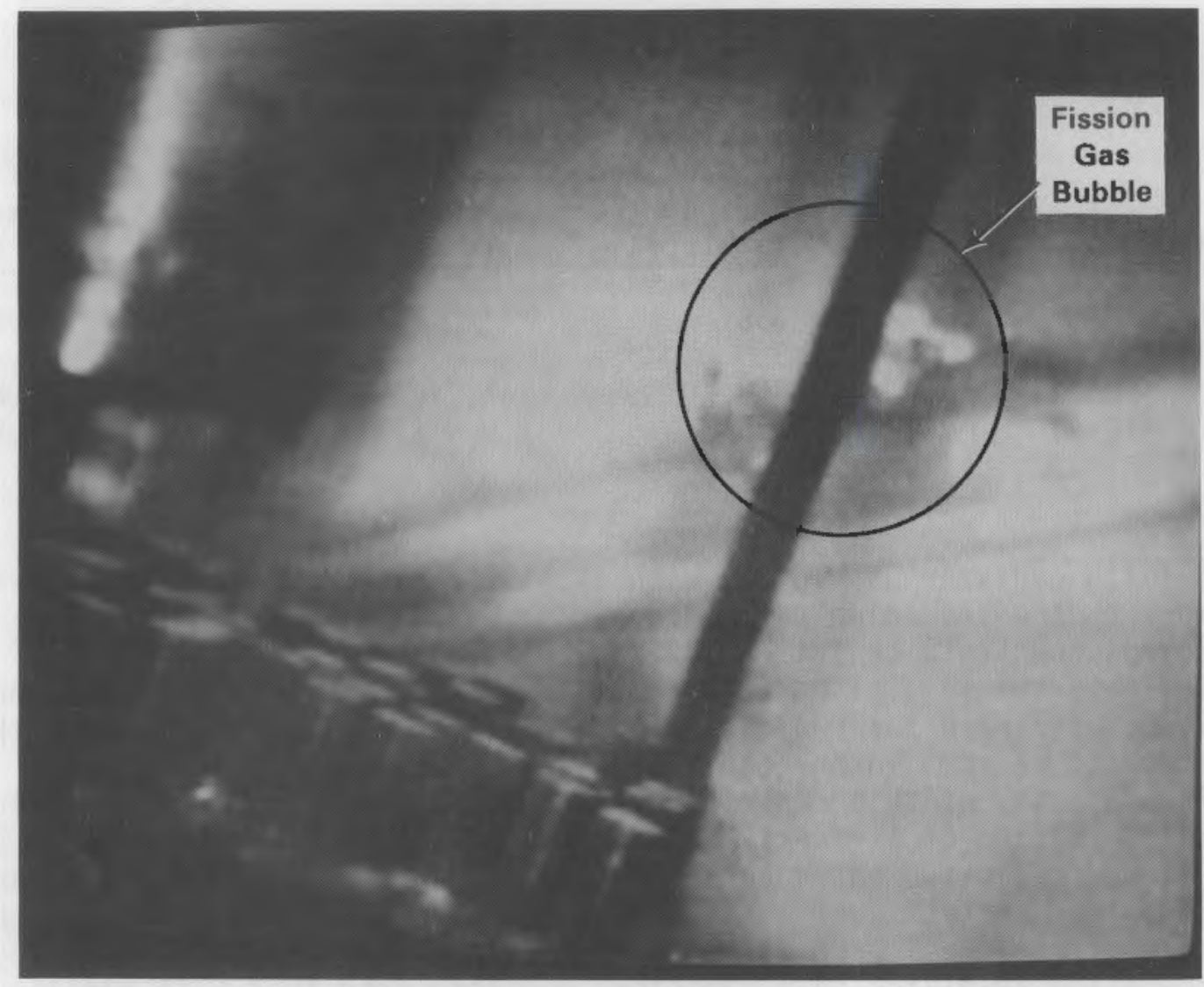

FIGURE 8. Fuel Rod with Collapsed Cladding that Released a Bubble of Fission Gas as the Rod was Being Pulled from the Fuel Assembly

The rod consolidation activities at the West Valley site did not result in significant exposure to the personnel. An exposure level of $0.6 \mathrm{mrem} / \mathrm{h}$ in a 1- to 2-mrem/h background was experienced (Fuierer 1986).

The compaction ratios attained at the West Valley site are shown in Table 1. No transition device was used to help hold the rods in a closepacked array as they enter the consolidation canister. The consolidation canister was tilted six degrees from vertical. In the Duke Power Company/ Westinghouse Electric Corporation rod consolidation demonstration, a transition device was used and a consolidation ratio of $2: 1$ was achieved (Bassler 1984). 
TABLE 1. Compaction Ratios Attained at the West Valley Site

\begin{tabular}{|c|c|c|c|}
\hline Canister $(\mathrm{a})$ & $\begin{array}{l}\text { Theoretical No. of Rods } \\
\text { That Could be Inserted } \\
\text { Into Canister }\end{array}$ & $\begin{array}{l}\text { Actual No. of Rods } \\
\text { Inserted In Canister }\end{array}$ & $\begin{array}{c}\text { Effective } \\
\text { Consolidation } \\
\text { Ratio }\end{array}$ \\
\hline $\begin{array}{l}\text { First } \\
\text { Second } \\
\text { Third } \\
\text { Fourth }(\mathrm{IC}-4)\end{array}$ & 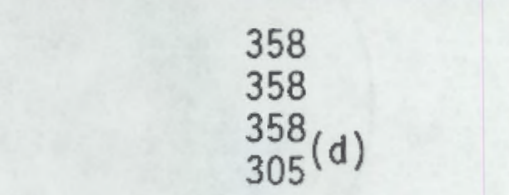 & $\begin{array}{l}109 \\
251 \\
251 \\
276\end{array}$ & $\begin{array}{l}0.6^{(\mathrm{c})} \\
1.4 \\
1.4 \\
1.8^{(\mathrm{e})}\end{array}$ \\
\hline
\end{tabular}

(a) A fifth canister was loaded with the 187 fuel rods left over from the work on the preceding canisters.

(b) Corresponds to a consolidation ratio of $2: 1$.

(c) Reflects the initial encounter with extreme rod flexibility and the associated need for rod directional and alignment control during the stacking of rods in the canister.

(d) The capacity of this canister was less than the other canisters because of a combination of as-fabricated dimensions, the addition of thermocouples (it was an instrumented canister), and a wide canister sealing flange.

(e) More representative of what the rod consolidation system (people, hardware, procedures) used at West Valley can achieve. After reviewing the operation involving this canister, NAC concluded that with additional control another row of rods (16 or 17) could have been loaded into this canister.

When rods are pulled out of the fuel assembly one at a time and placed in the canister one at a time, a difficult procedure is involved in maneuvering the rods into a close-packed array. RG\&E feels that control of the rod during its insertion into the canister is extremely important and is an area that needs considerable engineering attention (Fuierer 1986). NAC also indicates that their experience at West Valley provides clear evidence of the need for mechanical rod constraint and direction to lessen the demand upon human skills.

In general, the rod pulling proceeded smoothly, but pulling rods one at a time appears to be a slow operation. However, NAC points out that the history of this and other rod consolidation demonstrations shows that rod 
pulling, per se, is only a small portion of a rod consolidation program. Though the program extended from November 1985 through early April 1986, the actual rod pulling/consolidation operations took place in a very few days (December 26, 1985, through January 2, 1986, and February 18-21, 1986). other issues, such as procedures, quality assurance, setting up and dismantling of equipment, and compaction of the nonfuel-bearing structural components, are typically considered as secondary but are the real time consumers.

According to NAC, if mechanical rod control and direction (to ensure high consolidation factors and reduce human skill requirements) can be developed, the relative slowness of single-rod (or few-rod) pulling will be more than offset by the equipment's relative lower cost, reliability, and inherent ability to cope with off-normal situations. Also, a horizontal operation may be better for single-rod pulling than a vertical operation if compaction ratios close to $2: 1$ are desired, because the former would be aided by the force of gravity. (a)

Rod pulling times of two minutes or less were achieved when operators at the West Valley site gained sufficient experience (Fuierer 1986). For the first $51 \mathrm{~cm}$ (2D in.), rods were pulled at the rate of about $3 \mathrm{~m} / \mathrm{min}$ $(10 \mathrm{ft} / \mathrm{min})$, then the rate was increased to $9 \mathrm{~m} / \mathrm{min}(30 \mathrm{ft} / \mathrm{min})$ unti) the last $51 \mathrm{~cm}$ (20 in.) of rod were reached. The rate was then decreased to $3 \mathrm{~m} / \mathrm{min}(10 \mathrm{ft} / \mathrm{min})$.

Rochester Gas and Electric indicates that initial pulling forces were between 32 and 52 kilograms (70 to 115 pounds) and averaged about 41 kilograms (90 pounds) (Fuierer 1986). The continuous pulling forces required at the West Valley site were considerably greater than those noted in the earlier Duke Power Company/Westinghouse Electric Corporation rod consolidation demonstration and in data available from reconstitution operations. A pulling force of approximately 91 kilograms (200 pounds) was reached on the

(a) Stiens, R. E. (West Valley Project Office, (DOE). 1985. Memorandum to C. P. Gertz (Radioactive Waste Technology Division, DOE), "Rod Consolidation Project," dated December 30, 1985. 
stuck rod that released the fission gas bubble and on another rod that was stuck. However, the eventual removal of both rods required much lower pul1 forces. NAC observed that in neither case did these high pull forces appear to damage the rods. When PNL was at the West Valley site on February 24, 1986, another visitor mentioned that pull forces up to 136 kilograms ( 300 pounds) were needed to pull intact rods from a new, unirradiated PWR fuel assembly with damaged structural components at another site.

To aid in predicting trends of pulling forces and scratches for rod consolidation operations in general, several studies could be performed. Quantitative data on scratches produced specifically by the rod consolidation activities as a function of rod pulling force would be desirable for evaluation of the various rod consolidation techniques (e.g., horizontal and vertical orientation of the fuel rods, single-rod and multiple-rod pulling, wet and dry environment). Such data from mounted specimens could include measurements of scratch depths and photomicrographs that show whether the scratches penetrate the crud layer, the crud plus oxide layers, or the underlying metal surface (exposed Zircaloy can become susceptible to hydriding at low temperatures). RG\&E indicates that it would also be desirable to obtain data on rod pulling forces as a function of initial spring-to-rod forces in spacer grids, contact area, and burnup. 0ther factors that can or might affect rod pulling forces and the scratches that are produced include misalignment of the rod pulling devices, rod bow, fuel assembiy bow and twist, fuel rod defects, and damage to the nonfuel-bearing structural components of the fuel assemblies.

According to RG\&E, the difficulty in achieving compaction ratios close to $2: 1$ with rod consolidation techniques that do not employ a transition device (e.g., such as the technique used at West valiey) is due to the surprising flexibility and resiliency of the fuel rods, which were demonstrated frequently during the rod consolidation operations at West valley. A transition device heips hold the rods in a closely packed array as the rods enter the canister. The resiliency exhibited by the rods 1) has the benefit of providing confidence that fuel rods can withstand considerable abuse in handling without rupture or breakage, 2) has the disadvantage that directional and alignment control during stacking operations is extremely difficult, and 
3) indicates that rods must be constrained during rod consolidation operations if high compaction ratios are to be achieved. Because of the inherent flexibility, a bowed rod in a fuel assembly will likely straighten out somewhat when it is removed from the assembly and suspended vertically from its end. Therefore, RG\&E concludes that the evidence from the rod consolidation operations at West valley indicates that bowed rods will not be a problem once removal of those rods from a fuel assembly begins.

Based on the videotapes, it appears that no substantial damage to the cladding occurred that was attributable to the consolidation operation, al though longitudinal marks are visible on most rods. The marks do not appear to be deep scratches but looked more like areas where the corrosion product deposit (crud) had been scraped off as the rod passed through the spacer grids.

There is a two-stage filtration system located at the bottom of the fuel assembly holding rig to collect any particulate. A downward flow sweeps released crud into the filter system (Johnson 1986). Loose crud did not result in an increase in pool water radioactivity, and water clarity was maintained (Fuierer 1986). However, the water inside the rod consolidation canister clouded up because of crud released from fuel rods as they were inserted into the canister. (a)

It took about 15 to $20 \mathrm{~min}$ to cut the control rod guide tubes and remove the top end fitting (nozzle) from a fuel assembly to gain access to the upper ends of the fuel rods (Johnson 1986). After initial efforts to sever the control rod guide tubes resulted in broken cutters (an internal cutter was used), the equipment was modified to eliminate the problem.

Rochester Gas and Electric indicated that one of the biggest surprises occurred during the crushing and shearing operations on the nonfuel-bearing components (Fuierer 1986). The guide tubes broke apart in an explosive manner rather than in a smooth shearing manner. NAC provided explanatory

(a) Stiens, R. E. (West Valley Project Office, DOE). 1985. Memorandum to C. P. Gertz (Radioactive Waste Technology Division, DOE), "Rod Consolidation Project," dated December 30, 1985. 
material for this phenomenon. The NAC videotapes document that the guide tubes exhibited significant ductility during the extreme crushing operations and even when they were bent 90 degrees by misaligned shear blades. During shearing operations, the crushed tubes were first compressed into an almost solid mass. The actual cut began with a smooth shear of the tubes touching the advancing blade, followed almost immediately by fracture of the rest of the tube mass. This fracture was indeed brittle, almost "explosive" in nature, with small suspended particles and crud seemingly to "shoot" to the rear of the crusher/shear operations. Even so, a later view of the sheared guide tubes always showed an even, smooth cut line with no cracks evident.

Subsequent NAC investigations with various shear manufacturers and DOE-Idaho indicated that behavior observed is a classic shear cutting mechanism for relatively "thick" material (such as the compressed mass of sixteen guide tubes and one instrument tube). With material of this thickness, the cut starts with a smooth shear and continues with fracture.

In summary, NAC states that the videotapes of the shearing are indeed striking (and indicate a major cause of the debris created) but normal. If anything, the operation demonstrated that the guide tubes are tough, strong, and capable of bearing the weight of the fuel assembly during lifting. The control rod guide tubes are the load-bearing members when a PWR fuel assembly is lifted (e.g., out of the reactor core, a spent fuel storage rack, or a shipping cask). 


\section{REFERENCES}

ANS. 1983. "Spent Fuel Consolidation, Duke-Westinghouse Test Uses Actual Spent Fue1." Nuclear News 26(5):54-56, April 1983, a publication of the American Nuciear Society, La Grange Park, Illinois.

Bailey, W. J. 1985. Status of Rod Consolidation. PNL-5122, Pacific Northwest Laboratory, Richland, Washington.

Bailey, W. J., and G. H. Beeman. 1985. "Status of Rod Consolidation of LWR Spent Fuel," Trans. Am. Nucl. Soc. 49:95-96, June 1985. Complete paper is PNL-SA-12819.

Bassler, E. A. 1984. "Westinghouse Fuel Consolidation Experience." Paper presented at the Institute of Nuclear Materials Management Seminar on Spent Fuel Storage, January T1, 1984, Washington, D.C.

Duckworth, J.P. 1982. "Spent Fuel Storage at the Western New York Nuclear Service Center," in Proceedings of the Am. Nucl. Soc. Topical Meeting on Spent Fuel Storage 0ptions. Savannah, Georgia, September 26-29, 1982.

Duke-Westinghouse. 1983. Spent Fuel Consolidation Demonstration (Oconee Nuclear Station, Fall 1982). Nuclear Engineering Services Division of Duke Power Company and Nuclear Service Division of of Westinghouse Electric Corporation. September 30, 1983.

Fuierer, A. A. 1986. "Lessons Learned and Results of Consolidation R\&D Program to Date," a paper presented at the "Rod Consolidation Technology" Workshop during the Third International Spent Fuel Storage Technology Sympos ium/Workshop, CONF-860417, 2:W-238 through W-248, ApriT 8-T0, 1986, Seattle, Washington.

Johnson, C. R,. 1986. "Videotape of West Valley Rod Consolidation Project," a videotape presented at the "Rod Consolidation Technology" Workshop during the Third International Spent Fuel Storage Technology Symposium/Workshop, CONF-8604T7, 2:W-224, April 8-10, 1986, Seattle, washington.

Klein, K., A. B. Johnson, Jr., and W. J. Bailey. 1986. "Wet Storage in The U.S.A.: Recent Experience and Directions," PNL-SA-18310, a paper presented at IAEA Coordinated Research Program Meeting on Behavior of Spent Fue1 Assemblies in Extended Storage (BEFAST), Leningrad, U.S.S.R., May 26-30, 1986 . 
. 


\section{DISTRIBUTION}

No. of

Copies

OFFSITE

J. R. Hilley

U.S. Department of Energy

Office of Civilian Radioactive Waste Management

$\mathrm{RW}-30$

Washington, DC 2 D545

R. Bown

U.S. Department of Energy

Office of Civilian Radioactive Waste Management

RW-30

Washington, DC 20545

K. A. Klein

U.S. Department of Energy

Office of Civilian Radioactive Waste Management

RW-31

Washington, DC 20545

D. E. Shelor

U.S. Department of Energy

Office of Civilian Radioactive Waste Management

RW-32

Washington, DC 20545

R. E. Stiens

U.S. Department of Energy

Idaho Operations Office

785 DOE Place

Idaho Fall, ID 83402

L. Barret

U.S. Department of Energy

Forrestal Building

RW-33 (Room 7F-043)

1000 Independence Avenue SW

Washington, DC 20585
No. of

Copies
C. W. Conner

U.S. Department of Energy

Forrestal Building

RW-33 (Room 7F-034)

1000 Independence Avenue SW

Washington, DC 20585

E. L. Wilmot

U.S. Department of Energy

Forrestal Building

RW-33 (Room 7F-03i)

1000 Independence Avenue SW

Washington, DC 20585

J. S. Finucane

U.S. Department of Energy

Energy Information Administration EI -53

Washington, DC 20585

R. D. Nelson

U.S. Department of Energy

DP 331-MS 4B026

1000 Independence Avenue SW

Washington, DC 20585

J. Epstein

U.S. Department of Energy

Office of Civilian Radioactive

Waste Management

Washington, DC 20545

W. Stringfield

U.S. Department of Energy

Office of Civilian Radioactive Waste Management

Washington, DC 20545

C. P. Gertz

U.S. Department of Energy

Idaho Operations Office

785 DOE Place

Idaho Falls, ID 83402 


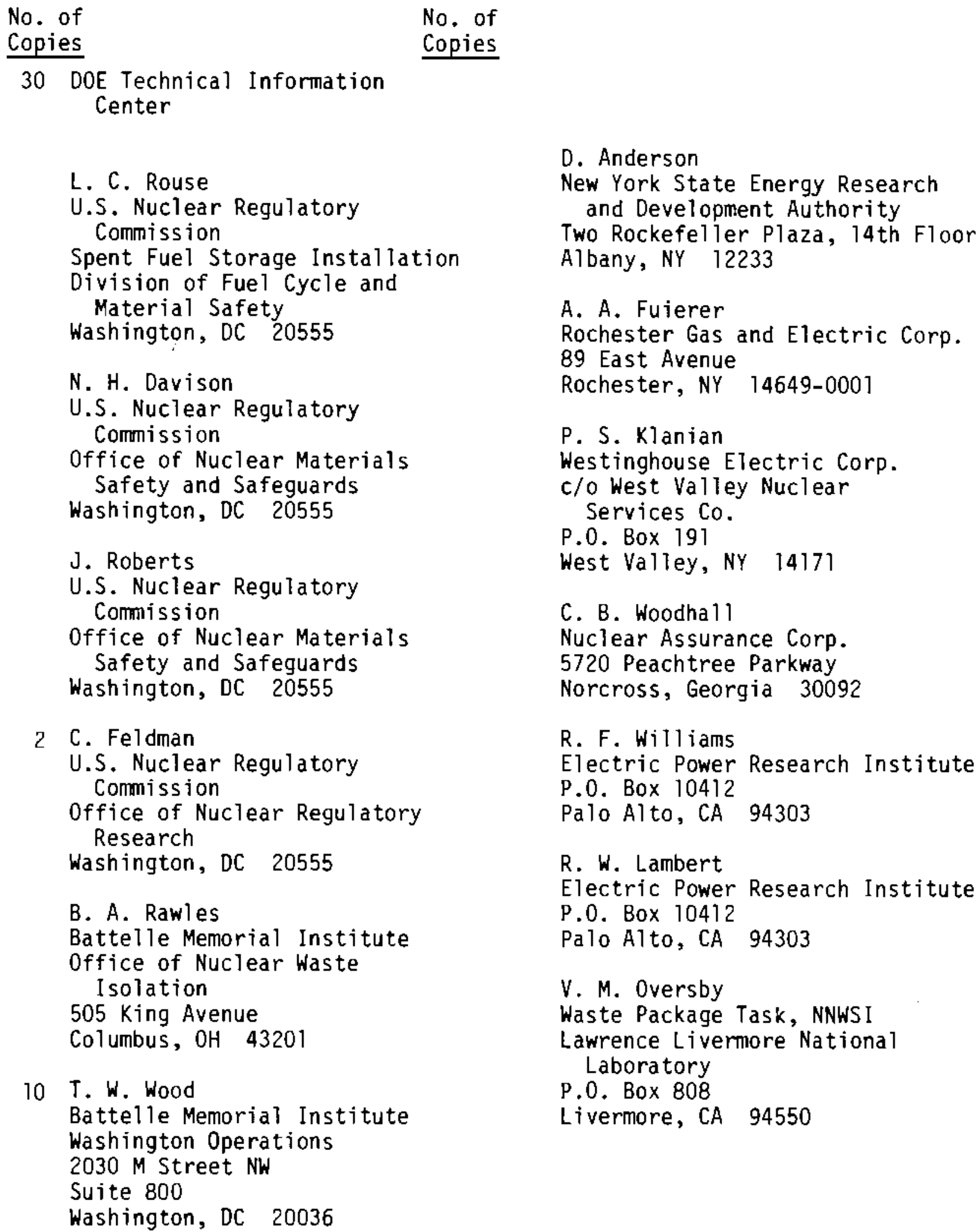


No. of

Copies

ONSITE

8 DOE Richland Operations Office

J. P. Collins

D. E. Crouter

R. D. Izatt (4)

D. C. Langstaff

J. J. Sutey

Rockwel] Hanford Company

C. L. Brown

42 Pacific Northwest Laboratory

W. J. Bailey (20)

G. H. Beeman

J. M. Creer

M. D. Freshley

E. R. Gilbert

R. J. Guenther

C. M. Heeb

R. E. Heineman

D. K. Hilliard

D. S. Jackson

A. B. Johnson, Jr.

J. L. McEl roy

D. F. Newman

J. T. A. Roberts

L. A. Strope

R. C. Walling

Publishing Coordination (2)

Technica] Library (5) 
